水文・水資源学会誌 J. Japan Soc. Hydrol. \& Water Resour. Vol.8. No.1 (1995) pp. 19-37

\title{
河川経済調查手法の体系化の現状と今後の課題*
}

\section{Status Quo of Economic Appraisal Methods for Rivers in Japan and Their Future Prospect}

\author{
竹林征三** (建設省土木研究所) \\ Seizo TAKEBAYASHI Public Works Research Institute, Ministry of Construction \\ 安田吾郎***（建設省近畿地方建設局） \\ Goro YASUDA Kinki Regional Construction Bureau, Ministry of Construction
}

\begin{abstract}
Economic appraisal guidelines and methodologies in Japan for river projects are compiled. The scope of the appraisal system in the whole range of social cost-benefit elements is delineated. Then, available nonmarket goods valuation techniques are discussed. We find that some of these techniques will be useful to aid the realization of the holistic appraisal of river projects although more accumulation of empirical studies in Japan is needed to assess how far these techniques should be incorporated into the appraisal system. The criterion of the assessment should be whether decrease of the allocative inefficiency can be expected more than the increase of the $\mathrm{x}$-inefficiencies caused by the surveys. Some supplementary discussion on empirical use of nonmarket valuation techniques in overseas countries is also made.
\end{abstract}

Key words: Economic appraisal, River projects, Nonmarket goods valuation techniques

日本における河川経済調查方法の現状を総括し, 社会的費用・便益の発生要素全体に対する現行調查方法の対象範囲を明らかに した. そして, 各種の非市場財評価手法の適用性を論じた，その結果，こ机らの手法の一部は河川経済調查手法の総合化のために有 用であると思われるが，どこまで現行の評価体系に組み入れられるか結論を出すためには国内における実積の積み重ねが必要であ ることを明らかにした，さらに，その結論を出すときの判断基準は, 調査の実施によって生じるX非効率の增大を上回る配分の非効 率の減少が得られる見込みがあるかどうかという点であることを明らかにした。また, 諸外国における非市場財評価手法の応用につ いて若干の補足議論を行った.

キーワード：経済評価, 河川事業, 非市場財評価法

\section{I 、はじめに}

河川関係事業は, 年間事業費 3 兆 5 千億円 (平成 5 年度実施額ベース ${ }^{34)}$ ) の規模を持つ公共事業であり, その国民経済上の役割は大きい。一方，河川事業を 通じて供給される財 り, 公共財に関しては, 最も効率的な資源 (財の供給
の制約要因となる因子, 金銭・労働力・水量等の各種物 理的要素等) の配分状態 (事業の内容の設定, 事業の地 域的・時間的配分等) は，自由市場のメカ二ズムに よっては達成できない。そこで, 河川事業に係わる 資源配分は，予算の大枠に関しては予算決定過程を 通じて定められ，細部は事業者の行政的判断により 決定されている。

\footnotetext{
*これは1994年 2 月の水文・水資源学会例会において竹林が報告した内容に加筆・修正を加えたものである.

**建設省土木研究所環境部 テ305つくば市旭 1 番地

Environment Department, Public Works Research Institute, Ministry of Construction, 1 Asahi, Tsukuba, 305

***建設省近畿地方建設局淀川工事事務所 $=573$ 枚方市新町 2-2-10

Yodo River Work Office, Kinki Regional Construction Bureau, Ministry of Construction, 2-2-10, Shinmachi, Hirakata, 573
} 
以上に述べた事業の大規模性と資源配分上の事業 者の意志決定の重要性を合わせて考えると, 河川事 業における配分の非効率 (Allocative Inefficiency) を 抑制する重要性が浮かび上がる。ここで，配分の非 効率とは, より大きな純便益（便益から費用を差し引 いたネット)を生み出す対象があるのに, 別の対象に 資源を投資することによって生じる非効率のことを 指す．配分の非効率の抑制には，事業の実施により 生じる便益と費用を適正に把握することが有効な手 段である。

このような考え方に基づいて，建設省は昭和 32 年 に河川砂防技術基準 (案) を作成し，この中で経済調 查方法を定めた.この内容は, 昭和36年に「治水経 済調査方針及びとりまとめ方法」として通達され, 昭和45年からは治水経済調査要綱と名を改めて経済 調査を実施してきている，また，昭和 45 年に作成さ れた河川・砂防技術基準（案）に基づき，治水事業の 実施に当たっては, 治水経済調査要綱の方法に基づ く事業便益が費用を上回ることを必要条件としてい る.

ここで, 治水経済調査要綱に基づく事業便益とは, 現在のところでは洪水汇濫による住宅・事業所・農
作物・交通通信施設の被害等による資産価値の減少 の防止による便益である. それ以外の洪水発生によ る様々な被害, 例えば人命損失, 健康状態の悪化, 思い出の品等の特別な意味を持つ家財の品失, 洪水 後の污染された家財の片づけの苦労, 洪水の再来へ の不安や，その他の二次的・間接的な被害の解消は, 便益の中には含まれていない。このように，現状で の治水経済調查要綱に基づく便益は, 社会的便益全 体よりも小さくなっている，測定される便益が過小 であるということは, 治水経済調查要綱に基づいて 選ばれる事業規模が最適規模よりも過小になる要因 があるということを意味する。

一方, 計画の最適規模は, 経済理論的には, 社会 的純便益が最大となる規模であるべきである。この 点に関して, 河川砂防技術基準（案）では，「便益 (b) と費用 $(c)$ の比が $1(b / c=1)$ までの治水投資が経 済的に妥当なものと想定されるので, $b / c=1$ の場合 の事業費を把握するとともに, 当該事業費に相当す る計画の規模, 計画高水流量, 施設計画等を把握す

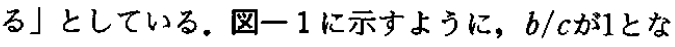
る最大の事業規模は, 外部性を考虑しない場合の最 適な事業規模, すなわち純便益が最大化される規模

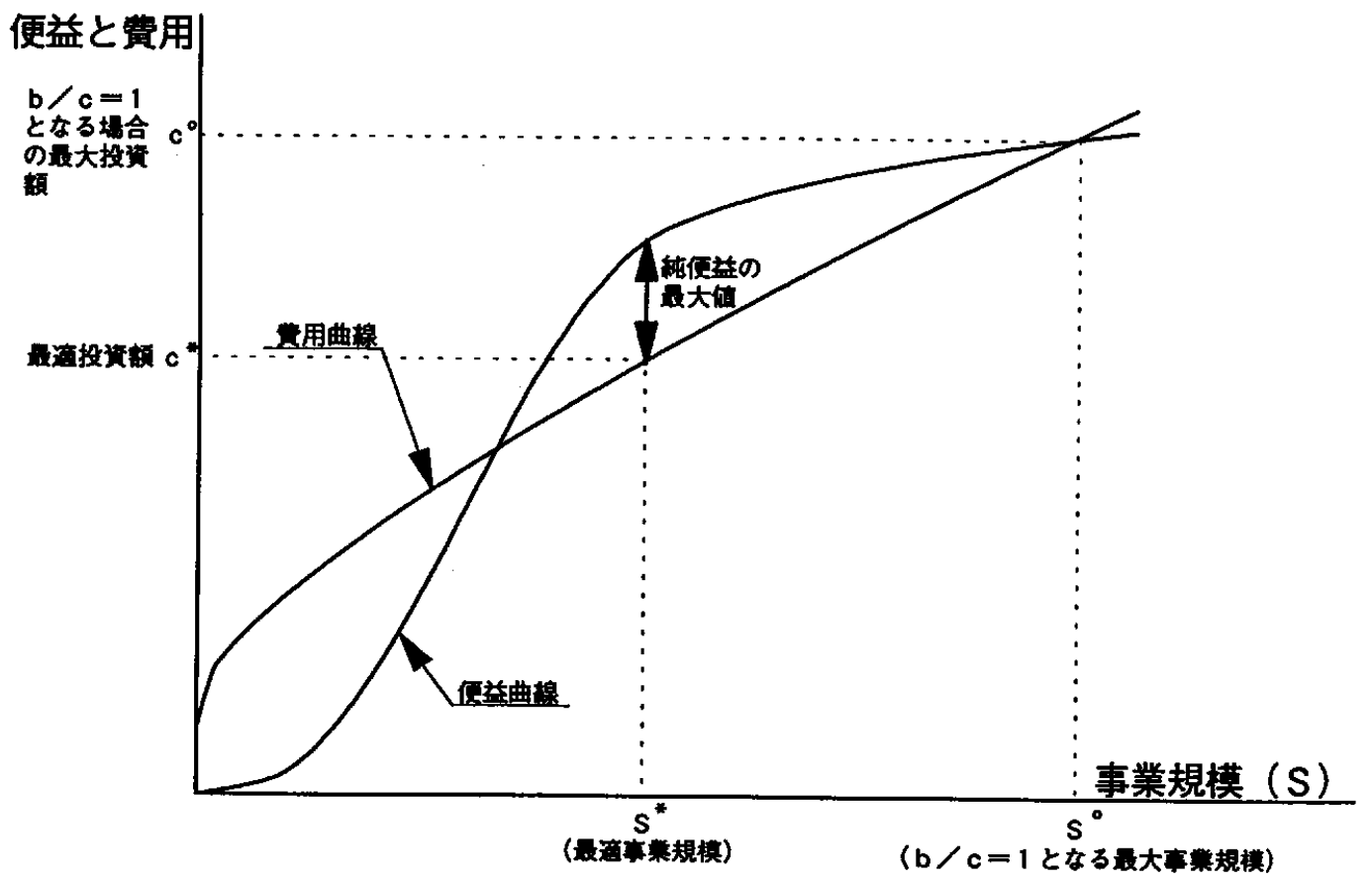

図一１最適事業規模と最大事業規模の閶係図 
よりも大きくなる，この場合には，最適規模より大 きな規模の計画が作られることになる．また，治水 経済調査において外部性(経済評価の対象外のもの) と して扱われているのは，便益項目ばかりではない。 環境へ悪影響が生じる場合には, 外部費用 (外部性の 内, 望ましくないもの）が存在することとなり，これ も最適事業規模の過大評価要因となる.

このように, 現行の治水経済調查要綱においては, 最適事業規模を過小に評価する要因と過大に評価す る要因とが存在する．この両者がバランスしている 限りにおいては, 配分の非効率は増加せず，加えて 経済調查コストを抑えられるというメリットとも合 わせて治水経済調查要綱及び河川砂防技術基準 (案)に基づく評価法は実用的に優れた手法であると いえる. しかしながら，過小評価要因と過大評価要 因とのバランスが崩れている場合には配分の非効率 は増加し得る。もしも，他の代替手法と比較した場 合の配分の非効率の増加に起因する費用が調查費用 節減便益を上回る場合には，そのような代替手法へ の改訂が考慮されてしかるべきである.なお，資源 の最適配分からの逸脱により生じる非効率を「配分 の非効率」というのに対して，同じ資源の投入に対 して出力の量に差がでる場合に, 最大の出力を生み 出せないセクターに存在する非効率を「X非効率」 という。経済調查の実施は, 配分の非効率を少なく する役割を持つ一方, 調查費をかけても結論が変わ らなければその分の調查費はX非効率の増大であり, 調查方法の最適化問題は, 調查に起因する配分の非 効率の減少とX非効率の増大とのトレードオフ問題 としてとらえることができる.

また, 治水経済調查要網は, マク口的な事業の全 体規模の決定には有効に働き得ても，ミクロ的な事 業要素間の資源配分の最適化のために用いることに はなじまないところがある，例えば，水質，景観， 生態等の環境への配慮のための妥当投資額に関して は, 環境の向上が治水経済調査要項における便益評 価の対象となっていない以上，その他の手段で行政 的意志決定を行わざるを得ない.

それでは，治水経済調查要綱に代替する経済調査 方法の構築は可能であろうか. 従来は, 環境や精神 的損失等の非市場財の価値の金銭評価は困難な点が 多いと見られてきた。意志決定者の判断に基づく資 源配分以上に効率的な資源配分が非市場財の金銭評 価の実施を通じて行えるとは見なされてこなかった のである.このため, 非市場財の経斉評価アプロー
チはわが国では実験的にしか行われていない.

しかし，非市場財の経済評価法は米国を中心とし て急速に発達してきている. 米国では1981年に制定 された大統領令 12291 号により義務化された大規模 事業・政策に係わる費用便益分析への対応を目的と して非市場財の経済評価法の応用が進んだ5 ${ }^{58}$ ほか, 1980年に施行 (1986年改正) されたスーパーファンド 法等に基づく環境被害額の計測方法を定めた1986年 （1991年改正）の自然資源被害評価規則（Natural Resource Damage Assessments Rule) ${ }^{66) 67)}$ では非市場 財の経済評価法を環境被害額の同定などのために用

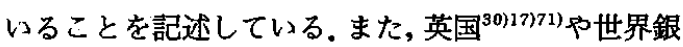
行 ${ }^{69)}$ でも環境価值の評価を事業評価ガイド等の中に 含めるようになってきている。OECDは，環境の経済 評価には解決すべき課題はたくさんありり年144), 政策 決定に使用するに当たっては多くの障害をクリアし なければならず44)，例えば道路の環境アセスメント への応用には否定的 ${ }^{45)}$ であるものの，現在の環境価 值評洒技術を用いた結果は許容できるレンジに収 まっており，今後一層の技術の向上が期待できると の判断を示している ${ }^{43)}$.

このような理論・応用の而面の進展を考慮すると, わが国においても治水経済調查要綱を発展させてよ り総合的な事業評価手法とすることができる可能性 が増えてきていると言える。

さらに，建設省は平成 6 年 1 月に環境政策大綱を 策定し，その中で「環境の内部目的化」という理念 を打ち出した。 今までは事業目的外の配慮事項ある いは制約条件として扱われていた部分のある環境悪 化の防止策あるいは環境の積極的向上策を, 事業の 本来目的に含めてとらえていこうというのがこの理 念の意味するところである.

この理念を事業計画の上に反映させる意味におい ても, 環境等の非市場財の洒值評価を含めた経済調 查法の確立のための検討は緊急に取り組むべき課題 となっている. 本論文においては，このような課題 に対する現在の状況と今後の展望について論じる. このため, II章において現在の経済調査法の体系に 関する概説を行った上で，III章において社会的純便 益の総合評価のための手法に関して論じ，さらに経 済評価手法の総合化へ向けた今後の課題と展望を明 らかにする. 最後のIV章においては，以上の総括を 行う. 


\section{II現行の経済評価体系と評価手法}

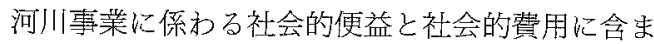
れる主な項目を図一2示す。このう占，中央の大 きな円の内側の範囲は，従来加ら便益としてとらえ らえてきたものである。但し，円の境界比まだっ て描かれている項目は，事業実施炕当たってある程 度の考虑はされていても経済評価の対象には通常含 ま水ない項目や，補償費等として建設事業費の中に 含まれていても, その額が実際の社会的損失の範囲 とは一致しているとは限らない項目である。

図一2の中て，現行の治水経済調香要綱に含まれ ている䈟囲は，「市場価值を持つ資産の保全」の項目 及び「鉄道・道路・通信網の確保」の一部である。 これ以外の部分まで含めた便益の評価体系として， 竹秝 ${ }^{63) 64) 65}$ 注，区一 3 の総合河川調查体系を提案し ている。この体系においては，治水経済調查要綱， 利水経佩調査要縌，噮境経済調查要網等により河川 事業に係わる便益の全体が評洒される。以下には， この体系中の治水経済調查要綱，利水経済調查要網 に関する経済調査法を概説する。環境経済調查要網 に関してはII章で議論する。

\section{1 治水経済調査}

治水経済調査要綱に基づく便益の評価〉ローを図 -4に示す。治水経済調查では，5～6 個の調查対 象流量のそれぞれに対応した想定被害額を算出し， その值に当該流量の生起確率を加け，流量に関して 積分することにより想定年平均被害期待額を求める。 想定被害額の算定比含まれる項目としては，一般資 産, 品菜停止, 公共土木施設等, 農作物加ある。一 般資座には，家屋，家庭用品，事務所，農・漁業の 償却資産，在庫資産が含まれ，公共土木施設等に泣， 河川施設, 㐤路施設, 橋梁, 農業用施設, JR・大手 私鉄, 電電, 電力の各施設が含まれる。

年当たりの便益は，想定年平均被書期待額加施 設の年維持管理費を差し引いた額として扱われてい る。一方，年当たりの費用は，用地費安含导事業費 そ施設耐月年数の中で均等に支払うものとみなして 求めている。減価補正計算（将来に発生する便篮・費 用を現在の価值に換算する計算）以用いる利子率は $45 \%$ とている。

以上の過程を経て，流量規模每に年当たりの純便 益が求められる。その結果に基づく事業規模の選定 法活I章で論じたと招りである。

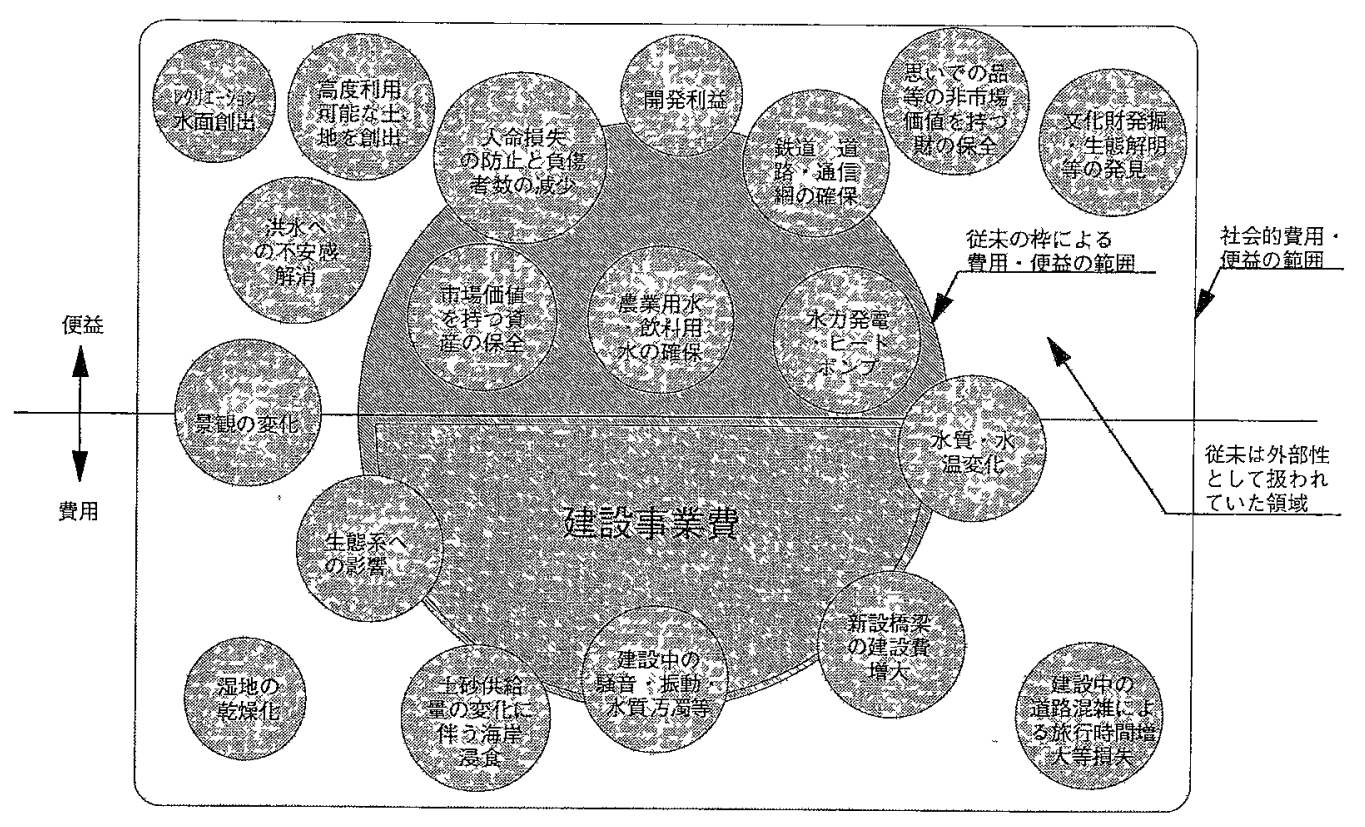

図一２河川事業における社会的費用・便益と従来の枠による費用・便益の範囲 


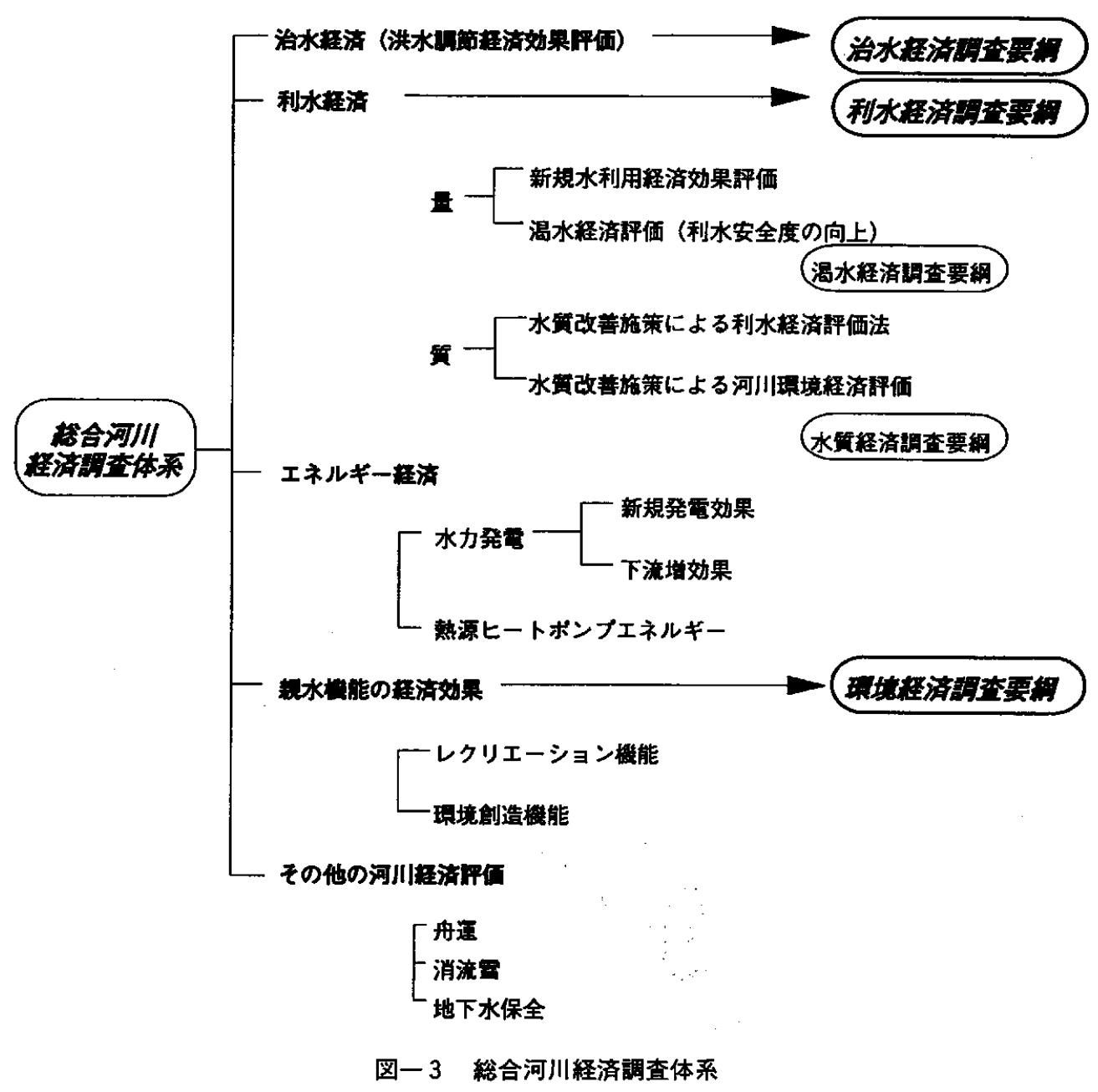

\section{2、利水経済調查}

水資源開発における上水, 工業用水, 農業用水に 係わる新規水利用の経済評価に関しては, 代替水源 の確保の方法, 水 1 トン当たりの值段, 穀物生産額 増加額等の評価方法が確立している.これらは, 多 目的ダム建設事業におけるコストアロケーションの ための妥当投資額算定の必要から手法が体系化され てきた経緯がある。水道については厚生省, 工業用 水については通商産業省, 農業用水については農林 水産省等がこれらの評価手法に取り組んできた。

以上の便益項目に加えて, 建設省では渴水対策事 業を昭和58年に事業採択し，さらには昭和63年度に 河川審議会から「渴水対策の推進方策について」と いう答申を得た等の状況から, 渴水対策の便益評価
の必要が生じた，例えば，渴水の生起確率を10分の 1 から20分の 1 にする，あるいは戦後最大あるいは 既往最大の渴水にも対応することを求める声に対応 した検討を行う際に渴水対策便益の把握が不可欠と なってきた．建設省では昭和55年の時点で「利水経 済調查要綱 (案)」を作成していたが，以上のような 情勢を踏まえて, それをべースとして渴水被害の経 済評価手法がまとめられた，その中では，图一5に 示すように，渴水被害防止を目的とした物品等の購 入費用や労働投入費用から，給水制限率の関数とし ての被害額関数を世帯及び各種業種に対して求め, それを対象地域内の各世帯・事業所に適用して被害 額を算定している.物品の購入に関しては，最大給 水制限率の関数として把握し, その他については各 


\section{治水経済調査に基つく便益評価フロー}

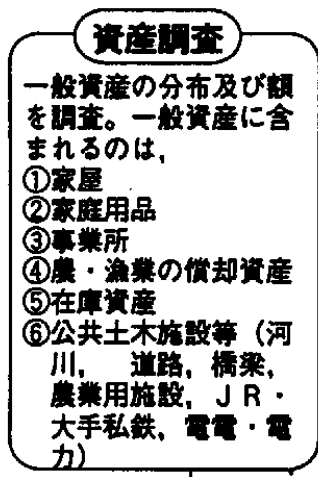

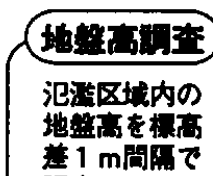

䣱查 t)

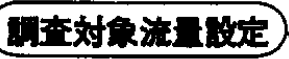 \\ 無零流青と罢用便前 比にと予想される流 鼻の間で $5 \sim 6$ 個の 源量を数定}
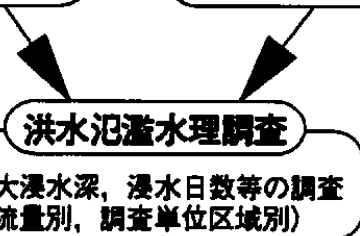

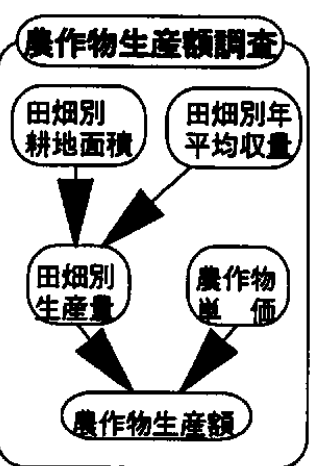

\section{破䆵率}

一般諼産については床上の 温水深玉たは土砧堆稓原别。 费作物については床上璂水 深または土砂堆积盀ならび に㵪水日数過去のデータに

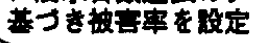

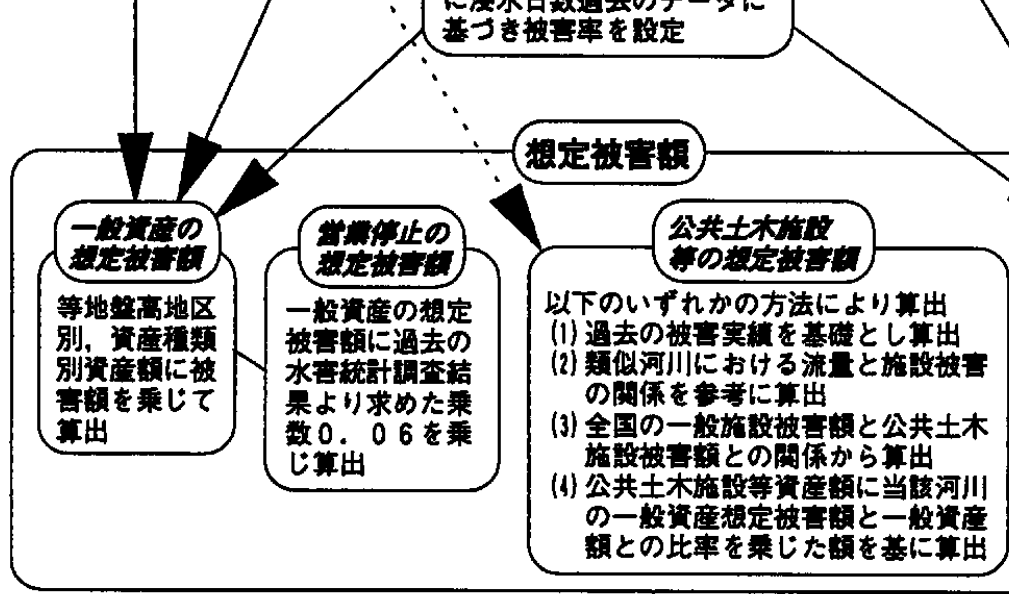

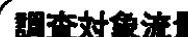
の生起墥䒠

\section{想定年平均被害蛏诚期待額（便益）}

図ー4 治水経済調查に基つく便益評価フロー 


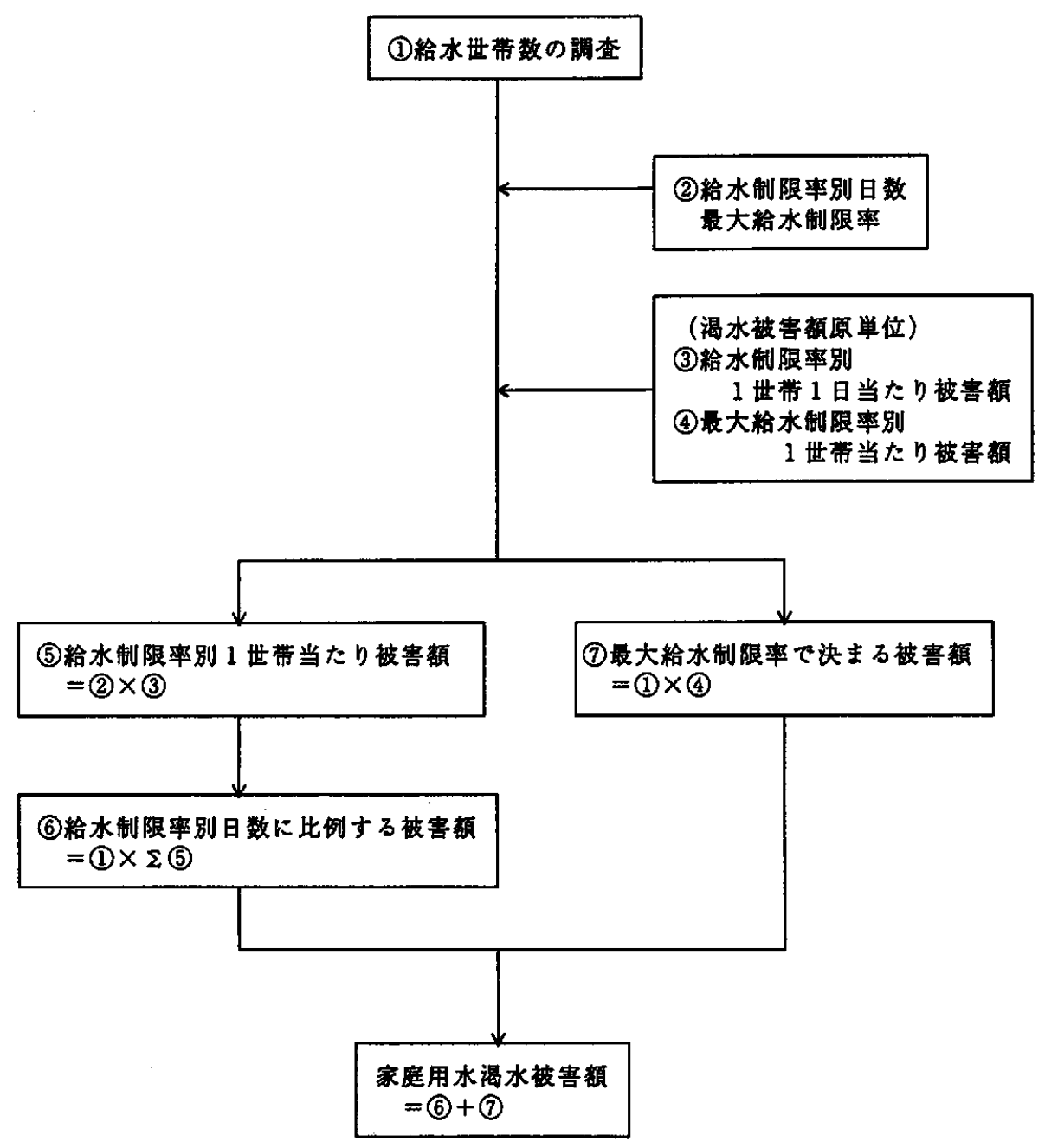

图一－用途別被富額算定手法フロー図

日の給水制限率から求める日毎の被害額に日数をか けて合計して求めている. 物品等の購入の中には, バケツや非常タンクの購入等が含まれる。また，労 働投入にはバケツリレーへの参加等が含まれる。こ れらのほか，渴水に起因して学校が休校になること 等の被害の評価も一応行っている. 以上の方法に基 づく渴水被害の算定法は実務的に用いられるように なっている.

次に，水質の改善価值に関しても，上水や工業用 水の水質净化経費の削減等の観点からの便益及び漁 業資源への影響の観点からの便益の評価方法がまと められている. 上水被害に関しては, 薬品費, 万過
洗浄費, 污泥処理費, 人件費等の維持管理費と処理 施設の建設費から求めた被害額と代替水源の確保費 用の内安い方を被害額と見なすことができる.水質 レベルに応じて処理費用は異なるので, 被害額は水 質の関数として表される.上水の維持管理費に最も 密接な水質指標として過マンガン酸カリ $\left(\mathrm{KM}_{\mathrm{n}} \mathrm{O}_{4}\right)$ 消 費量があり，万過・活性炭処理で対応しきれなくな りオソン処理が必要となる $28 \mathrm{mg} / \ell$ 程度を越えると 単位污濁負荷量当たりの処理費用は高くなる ${ }^{52)}$.

工業用水に関しても上水の場合と同様な考え方で 被害額を求めている。ただし, 工業用水の場合には 被害関数の因子としては濁度を用いている. 罣度が 
おおむね 10 30度であれば薬品沈殿処理で対応でき， 30〜40度であれば急速ろ過処理での対応となるため, 単位污濁負荷量当たりの処理費用はこれらの境界値 付近で不連続に変わる ${ }^{52)}$.また, 工業用水の場合には 産業によって許容可能な水質レベルが異なるので, 高級水を必要とする工場は高級水を必要としない工 場と区分して被害を求める必要があり，これらを区 分して被害額の算出を行う手法をとっている.

水質悪化に伴う水産被害に関しては, BODが変化 した場合に生じた水産資源への影響を日本全国の 104水系, 代表 6 魚種について分析し, その結果から BOD濃度の関数としての水産被害額の算定式を求 めている.

このように, 水質改善便益の算出方法はまとめら れてきているが，まだ実務的に用いられるまでには 普及していない，また，市場価値で測ることのでき ない価値についての評価方法は確立されていない. これに関しては, III章で詳しく論じる.

最後に, 水の持つ価值としては水力発電やヒート ポンプの熱源等の形によるエネルギー価值があるが, これに関しては通商産業省の長年にわたる検討に よって評価法が確立している。

\section{III. 社会的純便益の総合評価のための手法}

II章において, 治水経済調査要網及び利水経済調 查要綱の概説を行った。これらの内, 治水経済調查 要網と渴水経済調査要綱については既に実用に供さ れている一方, 水質経済調查要綱についてはほほ体 系化がなされているものの実用の一歩手前という段 階である。これらに対して, 謤境経済調查要綱の部 分に関してはまだ十分に調查手法はまとまっていな い. 社会的便益の総合評価のためには, 環境価値の 評価を組み入れることが必要であるが, 環境はその ほとんどの部分が非市場財の性格を持つために市場 価格を通じた価值評価を行うことができない. 本章 においては，この環境評価の問題を中心とした非市 場財の評価方法について論じる.

非市場財評価法にはいろいろな種類があり，それ ぞれに特色や固有の適用範囲，問題点を有している. 以下には，間接法と直接法とに全体を大きく区分し， 1 節及び 2 節で各手法の内容, 特幑, 適用性等を論 じる. 最後に 3 節において,これらの手法が河川事 業の社会的便益評価のために果たし得る役割につい て考察する。

\section{1. 間 接 法}

\section{1) 家計生産関数アプローチ}

非市場財の消費に当たっては, 何らかの市場財の 消費を必ず伴う場合や，逆に非市場財の消費と他の 市場財の消費が代替的関係にある場合がある。前者 の例としては, レクリエーションを楽しむためには， レクリエーションサイトまでの移動というサービス を消費しなければならないという関係をあげること ができる，後者の例としては，おいしくない水道し か供給されていない地域でおいしくない水の消費を 回避するためには, 市販の飲用水か净水器等の購入 が必要となる関係がある.このような非市場財と市 場財の補完関係や代替関係に着目して, 補完財ある いは代替財の消費性向から非市場財の価值を求める 方法を家計生産関数の利用による方法という。

家計生産関数の利用による方法のうち, 補完財・ 代替財への支出から非市場財への支払意志の下限を 求めるといった単純な手法を除いた中で最もよく使 われてきた手法が旅費法 (Travel Cost Method) であ る.旅費法の基本的なアイデアは1947年にHotelling

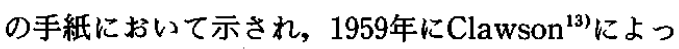
て初めて実際に用いられた。その後いろいろな手法 の改善の試みがなされてきているが，基本的な旅費 法による便益評価のフローを以下に示す.

(1)サイトを訪れる人数と，それぞれの訪問者がどこ からどのような交通手段で来たか，旅行目的は当該 サイトを訪れることだけかといったことを調べる。 (2)訪問者の住居位置を領域区分し，それぞれの領域 の人口重心点から当該サイトまでの道のり（道路交 通の場合）を算出する.

(3)当該サイトへの人口・年当たり訪問率と道のりと の間の関係を(各領域を 1 つの点として)プロットする. なお, 地域的な領域区分のみならず，収入等の因子 による区分を行う場合もある.

(4)単位道のり当たりの旅行に必要とする費用（燃料 費, 時間単価）を仮定し, 各領域から当該サイトま での旅行費用を算出する.

(5)訪問率対旅行費用をプロットし，旅行費用 $\mathrm{c}$ の関 数としての訪問率 $r(c)$ を求める.

(6)サイトの訪問コストが変動しても訪問費用の関数 としての訪問率は変化しないと仮定する.すると, 訪問費用を $p$, 領域 $i$ におる対象人口を $N_{i}$, 領域 $i$, ら当該サイトまでの旅行費用を $c_{i}$ としたとき，サイ 卜訪問コストの関数としての表される訪問頻度 $\mathrm{X}$ (p) は次式により示される. 


$$
X(p)=\sum_{i} N_{i} \int_{p}^{\infty} r\left(c_{i}+p\right) d p
$$

(7)便益 $(b)$ は，さらに次式で求められる.

$$
b=\int_{p}^{\infty} X(p) d p
$$

旅費法による便益の測定で留意が必要な点として は，以下のような点がある。

(1)時間の価値の評価

(2)複数目的の旅行の扱い

(3)代替サイトの扱い

(4)サンプル選択の問題

(5)サイトの持つ各種属性の評価の問題

時間の価値の評価に関しては, 移動中の時間価値 をどう評価するか, また, サイトにおける滞在時間 をどう評価するかという問題がある。前者に関して は, Cesarioの研究 ${ }^{12)}$ (賃金の25 50\%をレクリエー ション旅行中の時間価值とみる) 等により整理されて きたところである. 訪問サイトにおける滞在時間の 扱いは, 初期の旅費法では無視されていたが, Smith, et al . ${ }^{61)}$, Bockstael, et al. ${ }^{3)}$, Larson $^{37)}$ 等に よってその問題の重要性を明らかにされるとともに， 時間価値の計測モデルが提案されてきた。

次に，複数目的を持った旅行については，すべて の旅行費用を対象サイト訪問のためのものとみると 過大になるので補正が必要となる，また，代替サイ トが存在する場合には, 通常の旅費法では大きなバ イアスが生じ得るが, Bockstael, et al. ${ }^{2)}$ が複数サ イトを対象とした便益の測定法を提案しているほか, ランダム効用理論を組み合わせて複数サイト選択を 説明するモデルも用いられている ${ }^{4) 55}$. 複数サイトを 考虑したモデルの中でどれが適切かに関しては， Kling $^{35)}$ がモンテカルロ法を用いたシミュレーショ ンを行っているが，一般化可能な結論はでていない。 サンプル選択の問題としては, 対象地への訪問者 を対象とした調査に基づくデータを用いるか, 住民 からのランダム抽出等による母集団を用いるか, ま た，サイトを全く訪問をしない人のデータを含める かどうかという問題がある。 これらの問題について は, Smith and Desvousges ${ }^{60)}$ Smith $^{56)}$ がその扱い を論じている、また, 最近は, 訪問頻度計測の離散 性に起因するバイアスの処理法に関する研究なども 行われている20).

最後に, 通常の旅費法ではそれぞれのサイト全体 から生じるレクリエーション便益は測れても, サイ 卜の持つ各種属性 (例えば, 水䫝, 湖面の広さ, 付帯設
備の内容等) の持つ価值が測れないという弱点があ るが，属性別の便益まで評価する手法も開発されて いる.ヘドニック旅費法 (Hedonic Travel Cost Method ${ }^{9440)}$ は, 各属性に関する限界便益と旅費とが 均衡するものと見なして各属性の便益を求める.た だし，各属性の供給量が基本的に自然条件に依存す るため市場メカニズムによって価格と限界便益の均 衡が達成されない等の問題点からその応用を疑問視 する考え方もある ${ }^{4)}$.ヘドニック旅費法以外の旅費 法の派生手法でサイト属性を可能にするものとして は, パラメータ変化法 (Varying Parameter Model)が ある ${ }^{68)}$. パラメー夕変化法では,多数のサイトを対象 として各サイト毎に旅費法を用いて需要関数を求め, 各サイトへの需要の差はサイト属性の相違から生じ るものと考えて, 各種属性量を因子とした重相関分 析を行い各属性の価值を求める.この手法は, 簡易 指標の作成等を目的とした普遍的な価値評価を行う ための手法としては魅力あるものであるが, 膨大な 個別サイト毎の旅費法調查の実施が必要なことや， モデルの作成の仕方により結果が大きく変わるとい う問題もある ${ }^{59)}$.

\section{2) 土地価格に羊目した手法}

前節の家計生産関数アプローチが消費量の変化か ら需要関数を求めるのに対して, 価格の変化から需 要を求めていくアプローチがヘドニック・アプロー チである。

ヘト゚ニック価格法 (Hedonic Value Method) は, 地 理的位置に㷌属する財の価值は, 土地等の価格に反 映されることを用いて価值評価を行う手法で, 1974

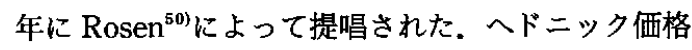
法では, 多数地点における地代または土地価格に環 境変数を含めた説明因子群によって重相関解析をか け, 各説明因子がどのような価值を持つのかが求め られる。地価に関してはキャピタルゲインを期待し た価格形成が行われたり，他の資産との間での税制 の非対称性の問題等があるため, 地価よりは地代を 用いる方が理論的には適切であるが，わが国では借 地市場が限定されている点や地価データが得られや すいこともあって, 実用的には地価データの方が一 般的に用いられている、ヘドニック価格法は，わが 国では地価データが比較的に整備されていることも あってか他の評価手法と比べて比較的応用例が多い. 諸外国ではむしろ応用例が他手法に比べて限定され ている ${ }^{58 / 44}$ 点からみると対照的な状況となっている。 ヘドニック価格法の実施に際して留意すべき点と 
しては以下のような事項がある.

(1)へドニック式の関数形選定

(2)属性選定の問題

(3)属性定量時の測定詥差の影響

(4)属性間の多重共線性

(5)対象範囲の設定

(6)需要関数の同定

(7)移動コスト

(8)咾好の多様性

(9)完全情報仮定

ヘドニック式の関数形としては, 基本的な線形モ デルの他に，片対数モデル，両対数モデル，ボック ス・コックス線形モデル, 二次式モデル，ボック ス・コックス二次式モデル等が用いられているが, どの関数形を用いるかによって各属性の評価值は異 なってくる. Cropper, et al . ${ }^{14)}$ は, 仮想の効用関数 と収入等の実データを組み合わせたデータセットを 用いて, 各種の関数形を与えてモンテカルロ法シ ミュレーションを行った.この結果, すべての属性 が正しく含まれている場合にはボックス・コックス 線形モデルとボックス・コックス二次式モデルが良 い結果を与え, 属性の同定に誤り（必要な属性の漏れ 等) がある場合にはボックス・コックス線形モデル のみがよい結果を与えるという結果が得られた。こ の結果の一般性に関しては検討の余地があるが, 関 数形の選定に関する有用な指針を与えているものと いえる。

ここで，属性の同定の誤りは，大きなバイアスを 生じさせる要因になり得ることが知られている ${ }^{48)}$. 例えば，Graves et al. ${ }^{24)}$ は，属性選定の仕方により， 視界の価値の評価が大きくことなるという結果を得 ている. また, Graves et al.は, 属性量の測定誤差 も大きなバイアスの要因になることを明らかにして いるほか, Epple ${ }^{23)}$ は, 土地価値と家屋価値の非分離 性もバイアスの原因となることを明らかにした。さ らに, 属性間で多重共線性がある場合には, 当該因 子群の価值評価には大きなバイアスが入り得る. 各 種の環境指標間には多重共線性がある場合が少なく ないので, このような場合にはそれぞれの要素の価 値を分離した計測を試みるには慎重な検討が必要で ある.

次に, 対象範囲については, 本来別々に扱われる べき領域を同一のものとして扱うと属性の評価には バイアスが生じる ${ }^{48)}$. 例えばある主要都市からの通 勤時間が主要な属性である圈域を対象範囲とする場
合に，誤って近隣の都市圈域を含めてしまう場合な どが該当する。

ヘドニック関数が求められることは，そのままで は需要関数が求められ，環境変化による便益または 費用が求められることを意味しない.ヘドニック関 数から需要関数あるいは付け值関数を求めていくた めには何らかの条件設定が必要であり, 多くの研究 者によって提案がなされている ${ }^{48}$.しかし,これはそ う容易ではなく、へドニック価格法を用いて限界便 益の評価までを行っている研究例は少ない ${ }^{58)}$.

この他のへドニック価格法の妥当性に影を与える 要因としては, 移動コストの扱いの問題, 赀好の多 様性の問題, 完全情報の仮定に関する問題がある. 住居の移動に際しては, 引つ越し費用の他に, 諸手 続に係る金銭的・時間的費用，新環境順応への費用， 旧環境下における人的関係の喪失に係わる費用及び 譲渡税，新居に関する情報の不完全性に起因するリ スクプレミアムが機会費用として生じる。しかし， ヘドニック価格法では通常移動費用をぜロであると 仮定している．移動費用が考慮される場合には, 計 測される便益に影響が及ふ心 ${ }^{48)}$.また,土地属性に動的 変動がありさらに喈好の多椂性も加味されると土地 価格形成への影響も大きくなる。さらに, ヘドニッ ク価格法では, 通常の多くの経済分析と同様, 市場 参加者はすべての場所の土地属性に関しての完全な 情報を持っていると仮定されているが，この条件を 緩めた場合の土地価格市場の形成についても一層の 検討が必要であろう.

以上,ヘドニック価格法の実施に際して留意すべ き点を論じてきたが，以下にはへドニック価格法に 類似した諸手法に関して簡単に触れる.

ヘドニック価格法が土地・家屋の属性が連続的に 変化し得る物としているのに対して離散的な選択し かできないとして家計行動をモデル化したのが離散 選択モデルである。このような離散選択モデルには， ランダム効用モデル49)やランダム付け値モデル ${ }^{221}$ が ある、これらの手法を用いた環境便益の評価事例は まだ少ない年が，最近行われたモンテカルロ法によ るCropper, et al. ${ }^{15)}$ のシュュレーションの結果で は, ボックス・コックス線形関数等を用いたヘド ニック価格法よりも離散選択モデルの方が良い結果 がでており, 今後の応用の進展が期待されていると ころである，このほか, 環境の価値が偊金に帰着す る可能性に着目した手法であるへドニック貨金法 (Hedonic Wage Model) ${ }^{54)}$ 等も, 広域にわたる単一市 
場の成立を仮定している等の問題点があるが、へド ニック土地価格法との融合に関する研究も行われて おり ${ }^{48)}$ 今後の進展が注目されるところである.

\section{2. 直 接法}

\section{1）仮想金鉞化法 (CVM)}

(1)手法の概略

代替市場や家計行動分析等の間接的方法ではなく， 対象者への直接的質問から需要を求める方法のうち の主なものは，仮想金銭化法 (CVM: Contingent Valuation Method) である. 仮想金銭化法は，擬制市 場法 ${ }^{62)}$, 価值意識法 ${ }^{46)}$, 意識分析法 ${ }^{28)}$, 意識に基づく 手法 ${ }^{29)}$ ，不確定評価技法 ${ }^{19)}$ などとも呼ばれる.仮想金 銭化法では，価值評価の対象とする財の内容を被験 者に説明し，その財を供給するために費用を支払う 必要があるとした場合に，支払っても良いと考える 金額の最大額を尋ねる (WTP法)。あるいは，ある財 の供給を中止する代わりに補償がもらえる場合に， 供給中止を是認するために必要な補償額の最小值を 尋ねる(WTA法)，WTA法で牥過大な額がでる傾问 があり，WTP法の使用が一般的に望ましいとされ ている ${ }^{1641)}$. 得られた支払意志額から, 対象地域全体 における支払意志額の合計を求める。その際には, 必要に応じて調査対象者の所得その他の因子と支払 意志額との相関解析結果を用いた補正を行う.

仮想金銭化法における主なバイアス要因は表一 1 に示すとおりである．この中から，以下には主要な 要素を取り上げて検討を加える。

(2)戦略的バイアス

戦略的バイアスとは，回答により自分に有利な結 果が得られるように答えるバイアスのことを言う。 ここで有利な結果とは，自分の費用負担が低くなる ことまたは対象財の供給確率が高まる(迷惑財であれ ば低まる)ことである。戦略的バイアスへの䅫念は仮 想金銭化法への批判の主要な論拠であった.しかし， $\mathrm{Bohm}^{566)}$, Brookshire et al.$^{8\}}$, Marwell and Ames ${ }^{39)}$ 等の研究により, 戦略的バイアスは実際に は適切な調査内容の設計を行えばそんなに問題とは ならないことが明らかにされてきた、この点に関し て, Mitchell and Carson ${ }^{41}$ ! は, 評価対象財の供給の 有無が不確実であるという設定にするとともに財の 供給された場合の対価の支払額も不確実であるとい う条件に設定した場合には戦略的バイアスが働きに くくなることを明らかにしている。

さらに，戦略的バイアスをほほ確実に無くす手法
である二分仮想金銭化法 (Dichotomous Choice

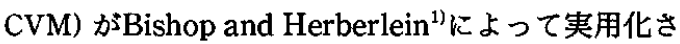
れ, Hanemann ${ }^{25}$ によって理論付けされた。この方 法では，被験者に付け值をしてもらう代わりにある 一つの額のみを提示し，この額を支払った上で対象 の財が供給される場合と，支払いをしない代わりに 対象財も供給されない場合のどちらが良いかを被験 者に尋ねる. 被験者毎に, 提示する額は変え, 多数 の調查サンプルから，提示額の関数としての肯定回 答率を求めることによって需要関数を求める.この 方法では，被験者に提示された世界を被験者が額面 通りに受け取る限りにおいて戦略的バイアスは生じ ない. なお，一人に一つの額を尋ねるのみでは大量 の被験者が必要であることから，一人に対して $2 つ$ の額を順次提示して尋ねる手法も応用されていると ころである ${ }^{26) 32)}$.

二分仮想金銭評価法の登場によって戦略的バイア スの問題には決着が付いた感があるが, Kealy and Turner ${ }^{33}$ は，通常の仮想金銭評価法と二分仮想金銭 評価法とによる平行実験を行い，二分仮想金銭化法 による方が,通常の仮想金銭化法に比べて1.5〜 2 倍 程度大きな值が得られたという結果を得ている。 た, Seller, et al ${ }^{53)}$ は旅費法, 通常の仮想金銭化法 及び二分仮想金銭化法の三者による平行調査を行い, 旅費法と二分仮想金銭化法では比較的に近い結果が 得られたのに対して，通常の仮想金銭化法ではそれ よりもかなり小さくなるという結果を得ている。通 常の仮想金銭化法では戦略的バイアスや財に関する 情報不足に起因する不確定性リスク回避等の要因加 ら実際よりも低い支払意志額がでている可能性があ り，以上の結果が一般的であるとすれば，今までの 通常の仮想金銭化法による調查結果は上方に修正す る必要があるということにもなり得る。二分仮想金 銭化法と通常の手法との一層の比較調査が期待され るところである。

\section{(3)追従バイアス}

追従バイアス（Compliance Bias）は，調査者に好 感を持たれないような回答を被験者が回避しようと して生じるバイアスである. 例えば, Duffield and Patterson ${ }^{21)}$ は, 魚類の保護を目的とした基金への支 払意志額を, 大学の名前と自然保護団体の名前で調 查を行い, 自然保護団体の名前ての調查の方が 5 割 程大きな回答となるという結果を得た。この調查て は，自然保護団体名の調查の方のみに，基金のパン フレットが配布されるという調查対称性制御上の問 


\section{衰一１仮想金鐡化法におけるバイアス要因}

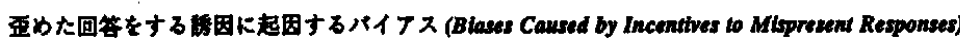

\begin{tabular}{|c|c|}
\hline $\begin{array}{l}\text { 酪的パイフス } \\
\text { (Straregle Bias) }\end{array}$ & 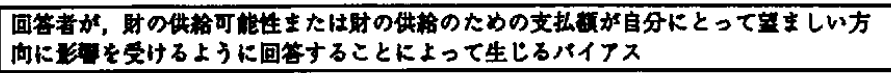 \\
\hline 追従バイフス (Compliance Btas) & 相手に毫ばれるような回答をしがちになることにより生しるパイフス \\
\hline 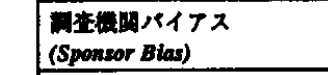 & 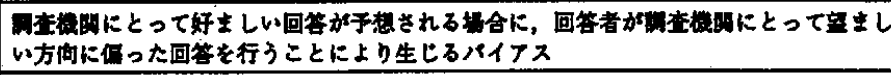 \\
\hline 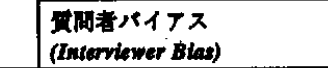 & 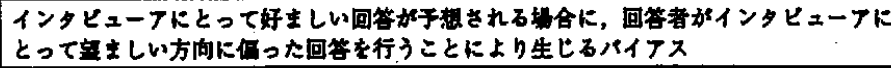 \\
\hline
\end{tabular}

研偭を暗示する手がかりにより生しるパイフス (Biases Caused by Impiled Cues)

\begin{tabular}{|c|c|}
\hline $\begin{array}{l}\text { 用始点パイフス } \\
\text { (Starting Point Bias) }\end{array}$ & 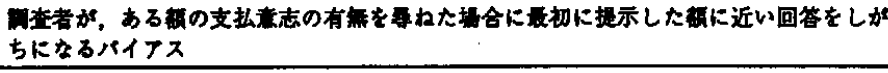 \\
\hline レンシハイイス (Range Bias) & 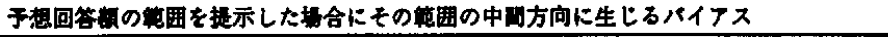 \\
\hline 閃パイフス (Relational Bias) & 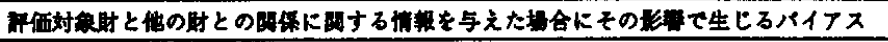 \\
\hline $\begin{array}{l}\text { T是性パイフス } \\
\text { (Importance Blas) }\end{array}$ & 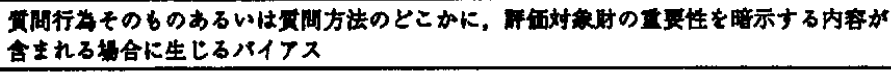 \\
\hline 位是パイフス (Postion Bias) & 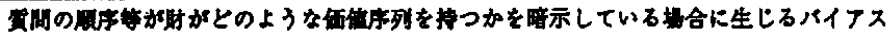 \\
\hline
\end{tabular}

シナリオの惺爵(Scenario Misppecification)

\begin{tabular}{|c|c|}
\hline 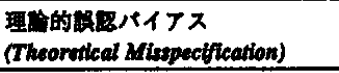 & 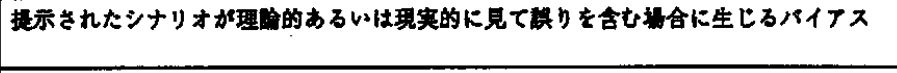 \\
\hline 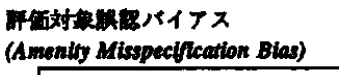 & 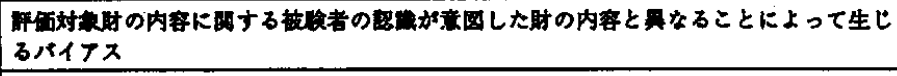 \\
\hline $\begin{array}{l}\text { シンボリックパイフス } \\
\text { (Symbollc) }\end{array}$ & 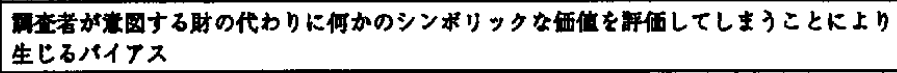 \\
\hline $\begin{array}{l}\text { 部分一全体バイフス } \\
\text { (PartoWhole) }\end{array}$ & 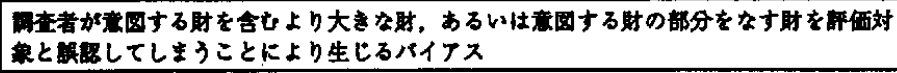 \\
\hline $\begin{array}{l}\text { 地理的部分一全体パイス } \\
\text { (Geographical Part-Whole) } \\
\end{array}$ & 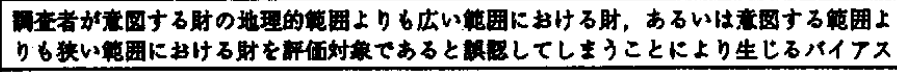 \\
\hline 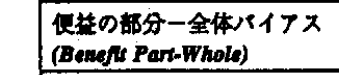 & 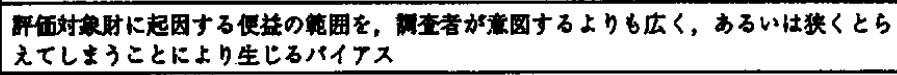 \\
\hline $\begin{array}{l}\text { 政策の部分ー全体パイアス } \\
\text { (Polley-Paickage Part-Whole) }\end{array}$ & 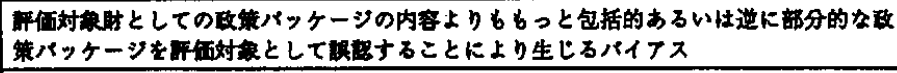 \\
\hline 尺度ハイフス (Metric) & 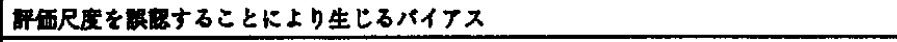 \\
\hline 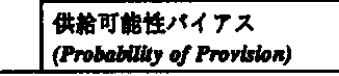 & 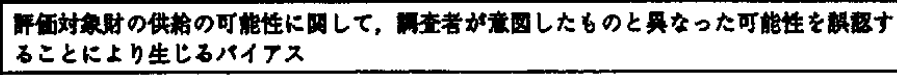 \\
\hline 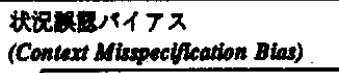 & 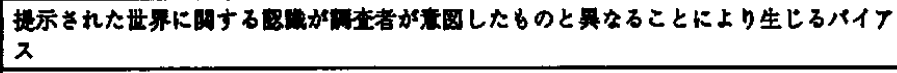 \\
\hline $\begin{array}{l}\text { 支払い保体パイフス } \\
\text { (Payment Vohicle) } \\
\end{array}$ & 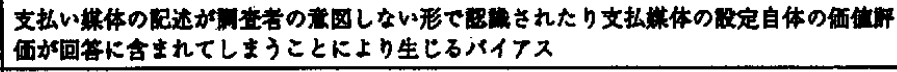 \\
\hline 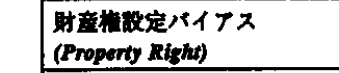 & 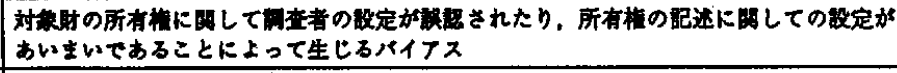 \\
\hline $\begin{array}{l}\text { 供吩方法ハイフス } \\
\text { (Mothod of Proviston) } \\
\end{array}$ & 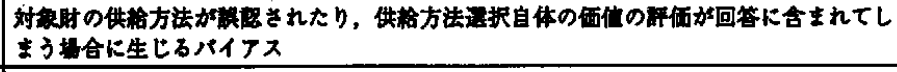 \\
\hline 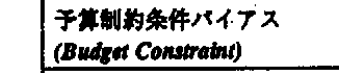 & 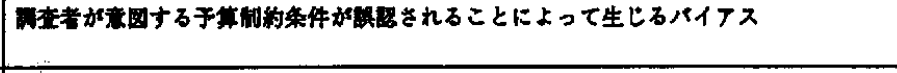 \\
\hline 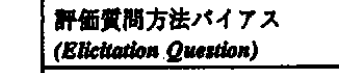 & 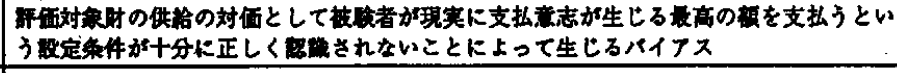 \\
\hline 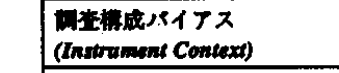 & 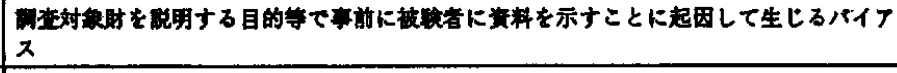 \\
\hline 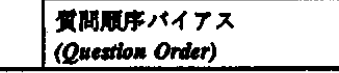 & 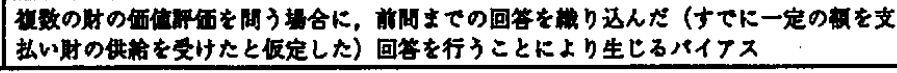 \\
\hline
\end{tabular}

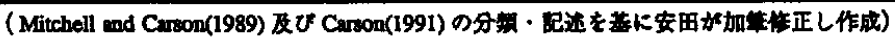


題はあるが，追従バイアスの影響の程度についての 有用なデータであることは間違いない.Yasuda ${ }^{70)}$ は, 追従バイアスを搪張した概念としての評判効果 (Reputation Effects)によるバイアスの問題に関する 効用理論分析を行っている. Yasuda ${ }^{70)}$ は効用水準に はその人の評判 ${ }^{\dagger+}$ が他者からの様々なサービス (例え ば, 暖かい言葉をかける, 内輪の荟荟に招くといったこ と）の提供に影響することに着目して,評判因子を織 り込んだ効用関数理論を表した。この理論を用いる と，仮想金銭化法による設問への回答が調查機関， 質問者はむろんのこと，友人・家族・自分自身から みた評判に影響する場合には効用水準の最大化のた めにバイアスが働くことが表される。なお， Laughland, et al ${ }^{38)}$ は, 社会的に望ましい方向に仮 想金銭化法の調查結果がバイアスされる可能性が高 いことを論じており，Yasuda ${ }^{70)}$ の論を別の角度から とらえたものと言える.

評判効果によるバイアスを少なくするためには， 匿名性を高めるか, 被験者から見て調査者が中立で 守秘義務に忠実であるように見られることが重要で あり,また, 回答内容が友人・家族からの評価に影 響が及ぶことが考えられるような場合には調査方法 について慎重な検討が必要である。一方, 正直に答 えることは多くの人にとって，自分自身に対する評 判効果にプラスの影響を与えると考えられることか ら，他の影響因子に比べてこの効果の比重を高める ような調查設計を行えば, 戦略的バイアス及び他者 からの評判効果に起因するバイアスの除去に有効で ある. Bohm ${ }^{6}$ が1984年に戦略的バイアスに否定的な 結果を得た実験においては，被験者には正直な回答 を行う重要性と責任が説明されており，この考え方 の有用性に関する一つの傍証を与えている，なお， Bohmが1972年に行った戦略的バイアスに対する否 定的結果を得た試験 ${ }^{5)}$ は, 被験者の実名入りの調查 結果を興味のある人には配布するという条件で実施 されている。この場合には，他者からの評判効果を 考慮して, 被験者が社会規範に沿った方向にバイア スされた回答をした可能性が高い. 従って,この場 合には，ただ乗り理論に対して否定的な結果である ことが，そのまま正直な回答であることを意味して はいないと考えられる。

(4)部分一全体バイアス

最近注目を集めている問題の一つが, 評価対象誤 認バイアスの問題である. 特に部分一全体バイアス, あるいはフレーミング効果 (Framing Effect) やエン
ベッディングバイアス (Embedding Bias) と呼ばれる 問題に関しての研究が盛んである. 部分一全体バイ アスは, 表一1に示されるようにいくつかの種類に カテゴライズできる、いずれも，評価の対象となる 財の範囲が不明確に提示された場合や誤解される場 合に生じる.例えばKahneman and Knetsch ${ }^{31}$ は, 公 共サービスへの支払意志額が，小項目への支払意志 額の積み上げ方式で尋ねるのと, 大項目への支払意 志額の分割方式で尋ねた場合に, 同一の公共サービ スに対する支払意志額が約10倍異なるという結果を 得た. Smith ${ }^{57)}$ Harrison $^{27)}$ が指摘したように, Kahneman and Knetschの設定では，部分一評価対 象のサービスの内容が極めてあいまいであり，部分 一全体バイアス，政策の部分一全体バイアス，質問 順序バイアス等のバイアスが強く働いており, 評価 対象財に係わる条件の不適切性がいかに結果に大き な影響を及ほしうるかを示したものとして彼らの研 究は意義がある。

最近では, Carson and Mitchell ${ }^{11}$ が部分一全体バ イアスに関する研究事例の総括を行っており, 報告 されているバイアス実例のほとんどが, 調査方法に 問題があるものか経済理論的にみて正当とは言えな いものであることを論じている. Carson and Mitchell ${ }^{11)}$ は, Desvousges, et al. ${ }^{18)}$ の研究結果が, 唯一の説明がやっかいな事例であるとしている. Desvousges, et al ${ }^{18)}$ は, 2,000匹, 20,000匹, 200,000 匹の 3 ケースの渡り鳥の命を救うための支 払意志額を尋ね, ケース間に有為な支払意志額の差 を見いださなかったのである。この結果について Boyle, et.al. ${ }^{7)}$ は一層詳細な検討を行っており, 経 済理論的に十分満足できる説明はできないという結 論を得ている. 2000匹以上の渡り鳥の救出のための 支払意志額の限界值がゼロでない限り，

Desvousges, et al.の結果は部分一全体バイアスの 影響を表したものと受け取れるが, Yasudaの評判 効果理論 $^{70)}$ を用いれば，観測された支払意志額はそ もそも評判効果によるものであり, 真の支払意志額 はほとんどゼロであると解釈することもできること を指摘したい.

(5)非使用価值 (Non-Use Value)

通常, 財の価值はその財を使用することにより生 じるものであるが, 財の使用を伴わずとも生じる価 値が非使用価値と呼ばれる. 非使用価值というもの がそもそも存在するかという点については異論もあ るが, 学会の趨勢は存在を認める方向にはある.ま 
た，先に取り上げた米国のスーパーファンド法及び 自然資源被害評価規則では, 被害の物理的復旧がで きない場合には污染者に存在価值分も含めた被害の 補償義務を課すことができるようになっており，米 国では行政的にも受け入れられているものと言える. 非市場価值を計測するのは間接法ではできず仮想 金銭化法等の直接法の適用が必要である.しかし, このようにして計測された值の妥当性については議 論が分かれている ${ }^{3651)}$.評判効果理論を適用すると, 仅想金銭化法で観測される非使用価値のほとんどは 評判効果によるものであるとの解釈も可能であり， この場合には先に挙げたようにDesvousges et $a l .{ }^{18)}$ の調查結果等も整合的に説明できるようにな る. 筆者は, 非使用価値の取り扱いには今後一層の 慎重な検討が必要と考える.

2) 仮想ランキング法

仮想ランキング法 (Contingent Ranking Method) は，仮想金銭化法とほとんど軌を一にするが，被験 者に金銭評価してもらう代わりにいくつかの財に関 する選好度のランク付けをしてもらいその結果から 財の価値を求める手法である，仮想金銭化法に比べ て便益の評価のためにはランキングにおける比較財 の価值評価を含めるステップが余計にかかるが，金 銭評価に抵抗がある場合などには有効であると考え られる.特に，わが国では仮想金銭化法の応用が進 んでいる米国と比べた場合には金銭で物事を測る考 え方に馴染めない人が多い可能性があり仮想金銭化 法よりも良い結果を生み出す可能性がある.

\section{3. 非市場財呯価手法の河川経斎調查への応用}

前節までに論じたように非市場財の評価手法には それぞれ課題点や適用可能な範囲があり, 河川事業 の実施に伴って生じる環境等の非市場財への影響の すべてを一つの枠組みで金銭評価するのは不可能で ある.

しかし，一方で多くの非市場財の評価が実用的に 可能になりつつあるということも言える，特に，応 用性の最も広い仮想金銭化法のバイアス除去理論が かなりの部分で確立してきたことは, 今後の非市場 財評価対象の幅を広げるのに大きく役立つと思われ る.この他の手法としては, 旅費法及びその派生手 法の応用もレクリエーション便益の評価の分野では 有用と思われる。 また，ヘドニック価格法に関して は, その基本的な問題の解決に一層の研究の積み重 ねが待たれるところである.わが国ではへドニック
価格法の使用に楽観的な論 ${ }^{28} も$ 見られるが, Smith ${ }^{58)}$ が大気污染の影響に関するへドニック価格法調查結 果のメタ分析を通じて指摘しているように, ヘド ニック価格法ては求める環境属性の限界便益評価ま で行なわれているのは希であるほか, 環境属性と地 価との間に統計的に有意な関係を見いだせないこと すら少なくない. $\mathrm{OECD}^{44)}$ も信頼性が比較的低い手 法という評価を下している.

いずれにせよ，わが国ではどの評価手法も適用実 績が少ない.さらに, 国内の既往の調査では, バイ アスに対して中立的とは言えないものもある.海外 の事例とのアナロジーが成り立たない部分もあろう と思われるので, 国内での事例の積み重ねが必要で ある. 例えば, 国土の狭いわが国では, 単一のリク リエーションサイトを訪問する目的で旅行する人は 米国等よりも少ないと考えられ，旅費法を適用する 際には多目的トリップの処理がよりシビアに求めら れるであろう。 また，奇付を集めるための家庭訪問 が頻繁に行われ，相応の額を寄付することが半ば社 会規範になっている欧米諸国とでは, 仮想金銭化法 への回答パターンにも違いがあると思われる，特に， 非使用価值の評価などにはずいぶん違う傾向が生じ てもおかしくないように思われる。 また，日本人は 周囲の人の目を欧米人以上に気にするとも言われ, これにより評判効果の効き方にも差が出てくる可能 性もある，既往の海外の仮想金銭化法調査では郵送 調査よりも対面調查の方が多いが, わが国の場合に は調查者バイアスがより大きくでる可能性があり， 識字率の高さとも相まって, 郵送法の適用範囲がよ り広いのではないかとも思われる。

章の結びとして, 图一 1 の便益・費用のフレーム の中で現在外部性として扱われている項目について, どのような評価法が適用できるのか整理してみよう。 まず, 図中の「洪水への不安感解消」や「思い出の 品等の非市場価値を持つ財の保全」, そして「景観の 変化」に関しては, 直接法が最も適した手法である う.「レクリエーション水面創出」に関しては, 旅費 法及びその派生手法と直接法が適用できよう。「水 質・水温変化」に関しては, 地先住民にとっての価 值に関してはへドニック価格法の適用も考えられな くはないほか, レクリエーション地におけるもので あれば旅費法及びその派生手法の適用も検討できよ う.また, 直接法はここでもやはり有力な適用手法 である. 次に, 人命や負傷の価値については, 賠償 金の額の算定に使われている逸失利益法のようなや 
り方もあるが，本人や家族の苦しみ等の価值はこれ では測れないので，ここでも仮想金銭化法は有力で ある. 実際に英国では，運輸省が交通事故防止便益 の算定に仮想金銭化法による調査結果をべースにし た評価額を用いている，また，死に至らないまでも 障害が残るような負傷を負った場合の損害に関して は, 仮想金銭評価法以外ではQALY指標 (Quality Adjusted Life Yearの略. 健常な状態における幸福度を 1 とし，死またはそれに等しい状態における幸福度を 0 とした物差しによって各種の病気や障害に対応した幸福 度を評価し，それに期待余命をかけて求める指標）を用 いた相対効用損失評価アプローチも医療経済の分野 で応用されており，災害防止便益の評価の上でも参 考になるであろう。

このほか, 表一 1 中の「新設橋梁の建設費增大」 や「建設中の道路混雑による旅行時間増大等損失」 に関しては, 特段の非市場財評価法を用いずとも評 価は可能である，外部性として扱っているものを内 部化して評価しさえすればよい.また,「生態系への 影響」,「湿地の乾燥化」,「土砂供給量の変化に伴う 海岸浸食」,「文化財発見・生態解明等の発見」に関 しては，事象とその影響との関係が明確とは言えず， 一般の人を対象とした仮想金銭化法を行っても意味 のある結果を得るのは難しいであろう. 専門家等を 対象としたデルファイ法や，デルファイ法で影響内 容の評価までを行った上で影響の金銭的評価は一般 人を対象とした仮想金銭化法により行う方法等が代 替手法としては考えられるが，どれだけ適切な評価 が可能であるかは対象の内容や学説の確立度等にも 依存するであろう. 次に, 「開発利益」の評価に関し ては, ヘドニック価格法や離散選択モデルを用いた 評価が行われているところであるが，仮想金銭化法 と組み合わせた評価なども検討に值しよう，最後に， 「高度利用可能な土地創出」の効果については, 部 分均衡モデルでは計測ができない世界になり, 都市 空間モデル等の一般均衡モデルの適用が必要になる。

以上, 現在外部性として扱われている各要素に関 する適用可能な評価手法を論じてきたが，これらの 評価の実施はX非効率の増大を伴うものであり,こ れらの実施が経斉的に正当化されるためには, 調查 実施による配分の非効率の減少が $\mathrm{X}$ 非効率の増大分 を上回る必要がある。このためには, 最低でも, 環 境経済調査を実施せずに事業計画者の判断で行う資 源配分以上に, 配分の非効率の小さい結果が環境経 済調查を通じて可能であることが期待できることが
必要であるが, 対象と適用手法によっては, この条 件が満たされない場合も多いと考えられ, 今後実例 を通じた一層の検討が必要である.

また，仮に現在の国民の選好の計測が経済調查を 通じて完璧に実施できたと仮定しても，この選好が， 官庁等の計画専門家等の判断する選好と比べて, 実 際に事業影響を受ける将来の国民の選好にどれだけ 近いかということが問題となる、日常的に体験する 環境の評価に関しては問題はあまり無いと思われる が, 非日常的なものや新技術等に関連したもの等に 関しては計画専門家等の判断による方が良い場合も 多々あろう。

このほか, 調査の適用の積み重ねの結果, 安定し た評価値が得られるものについては, 簡便評価法を 作ることも調查費用の削減の点で有効であろう. 米 国でレクリエーション需要の測定に用いられている 単位日価值法（Unit Day Value Method）はその一例 である。

以上, 非市場財評価法の河川経済調査要網への適 用性に関して論じてきた。結論としては, その応用 性は十分期待できるものの, 当面は調查実績を積み 重ねて, その中から適切な適用範囲を見いだすべき ということである.その適用範囲判断のクライテリ アは, 調查実施によるX非効率の増加を上まわる配 分の非効率の減少が得られるかどうかという点であ る.

\section{III. まとめ}

本稿においては, 河川経済調査実施の意義を論じ た上で, 現行の河川経済調查手法を解説した. 治水 経済調查手法に関しては建設省が定めた調查手法が あり, 利水経済調查に関しては, 建設省, 農林水産 省, 通商産業省がそれぞれの所管の分野における評 価法をほほ確立していることを述べた。一方で, 環 境経済調査の分野に関してはまだ定められた調査手 法はないほか, 治水経済・利水経済の分野において も非市場財の形態で現れる便益は評価に含まれてい ないことを述べた。

次に, 非市場財の評価手法は, 間接法と直接法と に大別され，間接法では旅費法等の家計生産関数ア プローチとへドニック価格法等の土地価格に着目し た手法があり，直接法では仮想金銭化法等の手法が あることを述べた、そして，これらの手法を概説し， その一般的適用性を論じた. 最後に, これら諸手法 の河川経済調査の総合化の上での適用性を論じた。 
以上の議論から，非市場財評価法の河川経済調査 への応用は有望であるものの当面は実績の積み重ね が必要であり，その結果から適用範囲を判断すべき であるという結論を得た。

\footnotetext{
†本稿での「財」は，西村 ${ }^{42}$ の定義によるものを用いる。 すなわち，「財」は，いずれかの国民の効用水準が高め られる物またはサービスを指す。なお，「糼用」とは， 消費者が欲求を充足することによって得る渵足を意味 する経済学用語であり，その满足の度合を数值化した ものが効用関数である ${ }^{42)}$. 河川事業により供給される 財としては，物理的な側面からとらえた場合には，改修 された河川,ダムその他の構造物等が挙げられる.サー ビスとしてとらえた場合には,洪水への安全の確保, 安 定した水供給の確保等が挙げられる。

サここでいう評判とは, 各種の評価要素を持つべクトル であり，人と人の組み合わせ毎に定義されるものてあ る. 評価要素としては, 例えば, 信頼性, 好感度, 尊敬 度といったものが教えられ。
}

\section{参考文畨}

1) Bishop, R.C. and T.A. Herberlein (1979): Measuring Values of Extramarket Goods: Are Indirect Measures Biased?, American Journal of Agricultural Economics, 61, pp. 926-930

2 ) Bockstael, N.E., W.M. Hanemann, and C.L. Cling (1986): Modelling Recreational Demand in a Multiple Site Framework, Water Resources Research, 22, pp. 777-787

3) Bockstael, N.E., I. Strand, and W.M. Hanemann (1987): Time and the Recreational Demand Model, American Journal of Agricultural Economics, 59, pp. 293-302

4) Bockstael, N.E., K.E. McConnell, and I. Strand (1991): Recreation in J.B. Braden and C.D. Kolstad (ed.) "Measuring the Demand for Environmental Quality", NorthHolland, Amsterdam

5) Bohm, P. (1972): Estimating Demand for Public Goods: An Experiment, European Economic Review, 3, pp. 111-130

6 ) Bohm, P. (1984): Revealing Demand for An Actual Public Good, Journal of Public Economics, 24, pp. 135-151
7) Boyle, K.J., W.H. Desvousges, F.R. Johnson, R.W. Dunford, and S.P. Hudson (1994): An Investigation of Part-Whole Biases in Contingent-Valuation Studies, Journal of Environmental Economics and Management, 27, pp. 64-83

8) Brookshire, D.S., B.C. Ives and W.D. Shulze (1976): The Valuation of Aesthetic Preferences, Journal of Environmental Economics and Management, 2, pp. 325-46

9) Brown, G.Jr. and R. Mendelsohn (1984): The Hedonic Travel Cost Method, Review of Economics and Statistics, 66, pp. 427-433

10) Carson, R.T. (1991): Constructed Markets, in J.B. Braden and C.D. Kolstad (ed.) "Measuring the Demand for Environmental Quality", pp. 121-162, North-Holland, Amsterdam

11) Carson, R.T. and R.C. Mitchell (1993): The Issue of Scope in Contingent Valuation Studies, American Journal of Agricultural Economics, 75, pp. 1263-1267

12) Cesario, F.J. (1976): Value of Time in Recreation Benefit Studies, Land Economics, 52, pp. 32-41

13) Clawson, M. (1959) Methods of Measuring the Demand for and Value of Outdoor Recreation, Reprint No. 10, Resources for the Future, Washington, DC.

14) Cropper, M.L., L.B. Deck, and K.E. McConnell (1988): On the Functional Form for Hedonic Price Functions, Review of Economics and Statistics, 70, pp. 668-675

15) Cropper, M.L., L.B. Deck, N. Kishor, and K.E. McConnell (1993): Valuing Product Attributes Using Single Market Data: A Comparison of Hedonic and Discrete Choice Approaches, Review of Economics and Statistics, 75, pp. 225-232

16) Cummings, R.G., D.S. Brookshire, and W.D. Schulze (1986): Valuing Environmental Goods: An Assessment of the Contingent Valuation Method, pp. 104-107, Rowman and Allanheld, Totowa, NJ, USA

17) Department of the Environment (1991): Pol- 
icy Appraisal and the Environment, pp. 167, HMSO, London, U.K.

18) Desvousges, W.H., F.R. Johnson, R.W. Dunford, K.J. Boyle, S.P. Hudson, and K.N. Wilson, "Measuring Nonuse Damages Using Contingent Valuation: An Experimental Evaluation of Accuracy" , Research Triangle Institute Monograph 92-1, Research Triangle Park, NC, U.S.A.

19) Dixon, J.A., R.A. Carpenter, L.A. Fallon, P.B. Sherman, and S. Monopimoke, 長谷川弘 (訳) (1991)：環境はいくらか一環境 の経済評価入門, pp. 61 , 築地書館

20) Dobbs, I.M. (1993): Individual Travel Cost Method: Estimation and Benefit Assessment with a Discrete and Possibly Grouped Dependent Variable, American Journal of Agricultural Economics, 75, pp. 84-94

21) Duffield, J.W. and D.A. Patterson (1992): Field Testing Existence Values: An Instream Flow Trust Fund for Montana Rivers, Paper Presented at Association of Environmental and Resource Economists Meeting, New Orleans, January

22) Ellickson, B. (1981): An Alternative Test of the Hedonic Theory of Housing Markets, Journal of Urban Economics, 9, 56-79

23) Epple, D. (1987): Hedonic Prices and Implicit Markets: Estimating Demand and Supply Functions for Differentiated Products, Journal of Political Economy, 95, 59-80

24) Graves, P.E., J.C. Murdoch, M.A. Thayer, and D. Waldman (1988): The Robustness of Hedonic Price Estimation: Urban Air Quality, Land Economics, 64, pp. 220-233

25) Hanemann, W.M. (1984): Welfare Evaluations in Contingent Valuation Experiments with Discrete Responses, American Journal of Agricultural Economics, 66, pp. 332-341

26) Hanemann, W.M., J. Loomis, and B. Kanninen (1991): Statistical Efficiency of Double-Bounded Dichotomous Choice Contingent Valuation, American Journal of Agricultural Economics, pp. 1255-1263
27) Harrison, G.W. (1992): Valuing Public Goods with the Contingent Valuation Method: A Critique of Kahneman and Knetsch, Journal of Environmental Economics and Management, 23, pp. 248-257

28）肥田野登(1992)：へドニック・アプローチによ る社会資本整備便益の計測とその展開, 土木学 会論文集, No. 449/IV-17, pp. 37-46

29）平松登志樹, 肥田野登 (1989)：河川環境改善効 果の計測手法の比較分析, 土木計画学研究 - 論 文集, 7, pp. 104-114

30) HM Treasury (1991): Economic Appraisal in Central Government - A Technical Guide for Government Departments, pp. 19, HMSO, London, U.K.

31) Kahneman, D. and J.L. Knetsch (1992): Valuing Public Goods: The Purchase of Moral Satisfaction, Journal of Environmental Economics and Management, 22, pp. 5770

32) Kanninen, B.J. (1993): Optimal Experimental Design for Double-Bounded Dichotomous Choice Contingent Valuation, Land Economics, 69, pp. 138-146

33) Kealy, J.K. and R.W. Turner (1993): A Test of the Equality of Closed-Ended and Open-Ended Contingent Valuation, American Journal of Agricultural Economics, 75, pp. 321-331

34）建設省 (1994)：平成 6 年版建設白書, 大蔵省印 刷局, pp. 376

35) Kling, C.L. (1988): Comparing Welfare Estimates of Environmental Quality Changes from Recreation Demand Models, Journal of Environmental Economics and Management, 15, pp. 331-340

36) Kopp, R.J. (1992): Why Existence Value Should be Used in Cost-Benefit Analysis, Journal of Policy Analysis and Management, 11, pp. 123-130

37) Larson, D.M. (1993): Joint Recreation Choices and Implied Values of Time, Land Economics, 69, pp. 270-286

38) Laughland, A.S., W.N. Musser, and L.M. Musser (1994): An Experiment in Contingent 
Valuation and Social Desirability, Agricultural and Resource Economics Review, 23, pp. 29-36

39) Marwell, G. and R.E. Ames (1981): Economists Free Ride. Does Anyone Else? Experiments on the Provision of Public Goods IV, Journal of Public Economics, 15, pp. 295-310

40) Mendelsohn, R. (1984): Estimating the Structural Equations of Implicit Markets and Household Production Functions, Review of Economics and Statistics, 66, pp. 673-677

41) Mitchell, R.C. and R.T. Carson (1989): Using Surveys to Value Public Goods - The Contingent Valuation Method, pp. 143-170, Resources for the Future, Washington, DC

42）西村和雄 (1990)：ミク口経済学, pp. 1-2, 東洋 経済新報社

43) OECD (1989): Environmental Policy Benefits: Monetary Valuation, pp. 63-65, OECD

44) OECD (1992): Benefits Estimates and Environmental Decision-Making, pp. 33-43, OECD

45) OECD (1994): Environmental Impact Assessment of Roads, pp. 40-41, OECD

46）大野栄治, 森杉壽芳, 星健一, 高木朗義, 高橋 靖英 (1993)：海面上昇対策による世帯便益の定 義について, 土木計画学研究・講演集No. 16 (1), pp. 1009-1014

47) O'Reilly, D., J. Hopkin, G. Loomes, M. Jones-Lee, P. Philips, K. McMahon, D. Ives, B. Soby, D. Ball and R. Kemp (1994): The Value of Road Safety - UK Research on the Valuation of Preventing Non-Fatal Injuries, Journal of Transport Economics and Policy, 28, pp. 45-59

48) Palmquist, R.B. (1991): Hedonic Methods, in J.B. Braden and C.D. Kolstad (ed.) "Measuring the Demand for Environmental Quality", pp. 77-120, North-Holland, Amsterdam

49) Quigley, J.M. (1976): Housing Demand in the Short Run: An Analysis of Polytomous Choice, Explorations in Economic Research, 3, pp. $76-102$
50) Rosen, S. (1974): Hedonic Prices and Implicit Markets: Product Differentiation in Pure Competition, Journal of Political Economy, 82, pp. 34-55

51) Rosenthal, D.H. and R.H. Nelson (1992): Why Existence Value Should not be Used in Cost-Benefit Analysis, Journal of Policy Analysis and Management, 11, pp. 116-122

52）佐々木才朗 (1992)：多目的ダムのコストアロ ケーションに関する研究, ダム技術センター

53) Seller, C., J.R. Stoll, and J.P. Chavas (1985): Validation of Empirical Measures of Welfare Change: A Comparison of Nonmarket Techniques, Land Economics, 61, pp. 156-175

54) Smith, V.K. (1983): The Role of Site and Job Characteristics in Hedonic Wage Models, Journal of Urban Economics, 13, pp. 296-321

55) Smith, V.K. (1988a): Travel Cost Recreation Demand Methods: Theory and Implementation, Discussion Paper QE89-03, pp. 1 -71 , Resources for the Future

56) Smith, V.K. (1988b): Selection and Recreation Demand, American Journal of Agricultural Economics, 70, pp. 29-36

57) Smith, V.K. (1992): Arbitrary Values, Good Causes, and Premature Verdicts, Journal of Environmental Economics and Management, 22, pp. 71-89

58) Smith, V.K. (1993): Nonmarket Valuation of Environmental Resources: An Interpretive Appraisal, Land Economics, 69(1), pp. 1-26

59) Smith, V.K. and W.H. Desvousges (1985) The Generalized Travel Cost Model and Water Quality Benefits: A Reconsideration, Southern Economic Journal, 52, pp. 371-381

60) Smith, V.K. and W.H. Desvousges (1986): Measuring Water Quality Benefits, pp. 212213, Kluwer-Nijhoff Publishing, Boston, U.S.A.

61) Smith, V.K., W.H. Desvousges, and M.P. McGivney (1983): The Opportunity Cost of Travel Time in Recreation Demand Model, Land Economics, 59, pp. 259-278 
62）末石富太郎十環境計画研究会（1993）環境計画 論一環境資源の開発・保全の基礎として, pp. 80-82, 森北出版

63）竹林征三(1992)：かが国における水量・水質の 総合管理とその経済評価, 国際水管理セミナー, pp. 12-20, (財) 国土開発技術研究センター

64）竹林征三（1993a）：水量・水質の総合水管理と その経済評価，土木技術資料，35(5)，pp. 2021

65）竹林征三 (1993b)：日本に抢ける水管理施策の 評価と計画策定・実施に至る過程一日本とオラ ンダにおける水管理施策立案過程の比較, Integrated Water Management Seminar論文集, pp. 41-64，(財)国土開発技術研究センター・ (財) ダム氷源地環境整備センター

66) U.S. Department of Interior (1986): Natural Resource Damage Assessments; Final Rule, Federal Register, August 1, pp. 27674-27753

67) U.S. Department of Interior (1991): Natural
Resource Damage Assessments; Notice of Proposed Rulemaking, April 29, pp. 1975219773

68) Vaughan, W.J. and C.S. Russell (1982): Valuing a Fishing Day: An Application of a Systematic Varying Parameter Model, Land Economics, 58, pp. 450-463

69) World Bank (1991): Environmental Assessment Sourcebook Vol. 1: Policies, Procedures, and Cross-Sectoral Issues, pp. 141149, World Bank

70) Yasuda, G. (1994): Proposal of the Reputation Model and its Application to the Contingent Valuation Method, MSc. dissertation, pp. 1-155, University of York.

71）安田吾郎（1994）英国の水政策における経済評 価手法（その1)，ダム技術，No. 93，pp. 1926

（受付：1994年 7 月27日，受理：1994年 8 月19日） 